$\mathbb{T}$ periodica polytechnica

\author{
Social and Management Sciences \\ $15 / 2(2007) 53+57$ \\ doi: 10.3311/pp.so.2007-2.02 \\ web: http://www.pp.bme.hu/so \\ (c) Periodica Polytechnica 2007
}

RESEARCH ARTICLE

\section{Accounting for emission rights}

Anita Reizinger-Ducsai

Received 2009-01-30

\begin{abstract}
The author summarises the advantages for the national economy of emissions trading and defines the aspects, on the basis of which the polluting facilities can decide whether they change in technology or purchase emission units. The emission units have pecuniary value, they appear in the accounts of the undertakings supervising the facilities. The place and value of the emission rights are not unambiguous in the accounts, the author presents the domestic and international rules thereof and their deficiencies.
\end{abstract}

\section{Keywords}

emission right $\cdot$ EU ETS $\cdot$ cap and trade $\cdot$ IFRS $\cdot$ right of pecuniary value

\section{Anita Reizinger-Ducsai}

Corvinus Egyetem, Budapest, 1093 Budapest, Fơvvám tér 8., Hungary e-mail: anita.ducsai@uni-corvinus.hu

\section{Introduction}

Emissions trading is one of the newest tools of environmental regulation. In the course thereof no individual limit values are prescribed for the individual polluting facilities, but the maximum emission is determined, that may be allowed in national totality for a given pollutant, and the polluting facilities are forced by economic stimulants to reduce emissions. In our home country the regulating body divides the maximum emission into freely tradable emission units - these units entitle the holder to emit one unit of pollution -, and the polluting facilities are obliged to monitor their emissions and to purchase emission units in a quantity corresponding to their real emissions.

If the offer of emission units is poor, i.e. there are less units than needed by the polluting undertakings, the market for emission units will be established and the emission unit will have a price. This price will be, on the one hand, integrated in the price of products involving the given pollution, and, on the other hand, it secures advantage in the competition for facilities polluting less than their competitors. We can establish that this regulation is more advantageous than the regulation by limit values based on facility, since in that case nothing stimulates the undertakings to reduce their pollution in excess of the fulfilment of the limit value.

The limit values draw a limit for the emissions of certain substances. The limit values in the regulation consider primarily the environmental quality as the main aspect. For the entity carrying out polluting activity the objective is that the value of the pollutant should not exceed the concentration or cumulative value fixed in the limit value. If it exceeds the value fixed in the limit value, this may entail various sections for the entity carrying out the activity, it may be obliged to pay a fine and in a more serious case this may entail even the suspension of the activity.

The emission trading realises, at the level of national economy, the reduction of emissions in the least expensive way. In the event of a regulation based on limit value the fulfilment of the limit value inflicts various financial burdens on each undertaking, depending on technology and other factors. However, in the event of emission trading the undertaking will itself decide whether it is worthwhile for it to produce the given product be- 
side the current unit price of emission, or it will be forced to stop the production or further develop its technology. As a result of this process, theoretically such polluting activities will be stopped, which create the least value added at the price of a unit of pollution.

\section{Theory of the market of emission rights}

The theory of the emission or "pollution rights" and of the trading therein is relatively new. In respect of the legal institutions serving the protection of environment it belongs to the tools of economic regulation. Certain pollution quotas, emission limits are established, to which each polluting entity (operator of facility) "is entitled". This may appear as contradictory from the aspect of environmental protection; therefore the use of the term "emission right" is more favourable, since a certain degree of emission of pollution is unavoidable in consequence of human activity. The entity entitled to emission may also dispose over its rights, thus if it remains below the emission value allowed for it, it may sell the remaining balance. And the operator of facility (undertaking), which purchased "the right to pollution", acquired thereby the right to a surplus emission larger than the value determined for it. Properly said, the market regulation forces dominate, in accordance with an economy's basic principle to economize and maintain cost efficiency. Nevertheless it may be purposeful also from the aspect of the reduction of environmental burden, since in the event of the correct determination of the quantity of all emission units to be distributed, the total emission will not increase in the course of the introduction of trading in emission rights, but this will stimulate both the seller and purchaser in the creation of revenues/saving of costs, and thereby to the emission of less pollutants. The seller makes a profit through the sale of further (pollution) units, while the purchaser strives to manage with less expenditure. Thus in the longer term it will be worthwhile for both of them to create investment projects for environmental protection purposes and to implement the change in technology.

In the course of change in technology the polluting entity seeks the application of the best and newest technology. But what is the best technology? As a starting point the European Union's Integrated Pollution Prevention and Control Regulation, called in public IPPC Directive (96/61/EC) may serve. The purpose of the Directive is a high-standard of environmental protection, through the integrated prevention and control of pollution derived as a consequence of industrial and agricultural activities. IPPC is a legal regulation, which obliges the industrial branches and technologies listed in the Appendix to obtain a licence from a designated authority. In the case of the non compliance their industrial or agricultural operations may be suspended or stopped. These industrial branches are wide ranging, from the oil, coal and energy industries through mining, metallurgy, textile, leather and chemical industries and waste industry up to the food industry.

The essence and at the same time the difficulty of the regulation is that it does not set up standards and limit values for the emission of pollutants or for the prevention and control of other environmental load, but entrusts it to the given Member States. Accordingly, the Member States are elaborating on their own licensing proceedings. According to the Directive the licence has to secure an integrated performance, i.e. the total environmental load of a given industrial facility must be taken into consideration, be it air, soil or water pollution, generation of waste, utilisation of basic material, energy efficiency or noise pollution.

The general condition of obtaining the licence will be that the given industry applies the Best Available Techniques (BAT). Of course, the question arises at once: what are the just "best available techniques" in the case of a given branch of industry and what is the cost of the compulsory application thereof? We do not undertake now to provide a detailed explanation of the subject, for the time being it should be sufficient that the Directive provided 11 years for the transition, for the implementation of the regulation, the provisions ought to have been fully performed by October 2007. Subsequently - due to the weakness of the regulation - the Commission accepted the new draft directive on industrial emissions on 21 December 2007. The draft is the reworking, into a single clear and logical legal norm, of seven existing directives relating to industrial emissions. The reworked version includes also the IPPC Directive.

The market of emission rights suitable for trading has been created in the interest of the agreement. The undertaking participating in emission trading must hold an emission licence, it has to be included in the national register and it is obliged to introduce proceedings of monitoring and data supply.

The undertaking must secure that the emission rights are presented in the accounts. These "assets" appear in the books, in the balance sheet, they may create costs and revenues and exercise direct influence on the value of the shares of the company.

At the beginning a carbon dioxide emission quota amounting to 2.23 billion tons had been assigned to the European Union (during the trial period between 2005 and 2007 and then during the first commitment period from 2008 to 2012), as opposed to the full emission of the world amounting to 25 billion tons, which caused a direct deficit of around 3\% on the market of emission trading.

The voting early in October 2008 of the Environmental, Public Health and Food Safety Council of the European Parliament on the proposal of the climate package entitled "On the Division of Common Burdens" projects the increase of opportunities connected to emission rights, the enlargement and movement of the market. The Council voted for a $30 \%$ reduction of the greenhouse gases relating to the period between 2013 and 2020, as compared to the level of 1990.

\section{Accounting issues of emission trading}

The participants in the Emissions Trading Scheme of the European Union (EU ETS) ${ }^{1}$ are granted emission units, so-called quotas on an annual basis, fixed at Government level, according to an allocation plan approved by the European Commission. The scheme allows that the quotas become commodities, they can be freely traded throughout the entire European marketplace.

The Hungarian State distributes, at no charge, $97.5 \%$ of the

1 The European Union Emission Trading System (EU ETS) is the largest multi-national, emissions trading scheme in the world, and is a major pillar of EU climate policy. 
quota quantity, available for the branches participating in the scheme, among the facilities, while it sells the further $2.5 \%$ units at auction. The operator shall monitor the emission of greenhouse gases subject to the emission licence on the basis of a separate legal rule and prepare an authenticated report thereon for the environmental authority by 31 March of the year following the subject year. The distributed quotas must be returned to the State by 30 April each year, if the entity is unable to perform this, then it will pay a fine (EUR 100/ton) on each ton not covered by the quota of emission, and in addition it has also to take care of purchasing the missing accounting units.

The accounting treatment of the emission rights is different in the Hungarian regulation and in the international recommendations. The Accounting Act [22] and the Standards treat a number of issues in a different way or they cannot solve them.

Act LX of 2007 [20]defines the Kyoto units as a right of pecuniary value. However, the categorisation is not nearly so unambiguous.

According to the Accounting Act, the pecuniary elements serving the operations of the entrepreneur, made available for the entrepreneur, shall be shown as assets in the balance sheet (Section 23 (1)). The following conditions must be met so that an asset can be included in the balance sheet:

- they have an economic value

- they can be valued independently, i.e. their value can be expressed in the form of cash,

- they are marketable independently, i.e. they can be alienated even individually.

Examining the emission rights we can state that it is about an asset to be utilised in the future, which has economic value as a condition of the operation of the undertaking and/or as potential object of sales on the market.

On the basis of the National Distribution Plan [27] the undertaking acquires ownership title to the right of pollution allocated to it, since the managing party will be entitled to possess, use and dispose over the thing (substantial elements of ownership title). The measurement unit of the emission quotas is the equivalent of 1 ton of $\mathrm{CO}_{2}$, which may be expressed in the form of cash. The marketability may be monitored, since the trading in the quotas is made on a more and more animated market.

If the emission rights perform the criteria of capitalisation, it has to be examined, in what a balance sheet group the emission right may be categorised in the balance sheet.

Does it serve the activity of the undertaking over a year or within a year, for what purpose it has been acquired by the undertaking, when the obligations connected to it have to be performed, does it wish to sell it, in what quantity the undertaking has to dispose of such assets.

If the undertaking as polluting entity (operator) ${ }^{2}$ disposes of emission rights, then this shall be considered, in harmony with

\footnotetext{
${ }^{2}$ As of 1 January 2005 greenhouse gases may be emitted, in our country, only
}

Act LX of 2007, as a right of pecuniary value. According to the Accounting Act rights of pecuniary value are acquired rights, which are not connected to real property. The emission quota is a basic entitlement, which serves permanently the operations of the undertaking, since the emission licence and the right to pollution acquired on the basis thereof mean the basic conditions of the continuance of the undertaking. At the same time we must see as well that the emission licences are distributed on an annual basis and they have to be accounted for also on an annual basis. Taking into consideration the prescriptions of the Accounting Act, the emission unit - if it is used more than one year later -, must be shown among the invested assets as intangible asset, namely the quota not used in the given trading period may be carried over to the next year. If the operator uses the quota in the given year or perhaps sells it, then it has to record it as commodity among the current assets.

However, other players may also appear on the market besides the operators. These may be other undertakings - which will be regulated only later, e.g. chemical industry, transport -, institutional investors - who purchase emission rights for the purposes of investment -, or organisations of environmental protection and private individuals - who purchase rights for the purposes of environmental protection, so-called deletion. They have to show and evaluate this element of assets depending on the issue, what a purpose they have with it. The Capital Market Act qualifies as investment assets the option, forward and other derivative transactions relating to greenhouse gas emission units and air pollutants emission rights, whose fulfilment is made through cash accounting and whose trading is made on a regulated market, and the accounting for which transactions is carried out by an accepted clearing house in line with the obligation to provide continuous security [23].

\section{A revoked interpretation - what does the emission right mean according to the IFRS}

In the International Financial Reporting Standards (IFRS) ${ }^{3}$ an asset may be categorised as an intangible asset in the event of the joint existence of the following conditions:

- identifiable element of property,

- non-monetary,

- has no physical appearance,

- its purchase value can be reliably measured,

- furthermore, it can be made probable that future economic gain will be realised, which can be ascribed to the asset.

IASB revoked, in July 2005, the interpretation IFRIC 3 "Emission Rights" accepted in May 2003. Since no newer interpreta-

in possession of an emission licence issued by the National High Surveillance of Environment and Water, i.e. the "Green Authority". Schedule I to Directive 2003/87/EC defines the scope of the facilities covered by the Directive [14].

3 International Financial Reporting Standards

${ }^{4}$ International Financial Reporting Interpretation Committee 
tion or standard has ever been made since then, it is worthwhile to look over in brief, what was contained in this position.

The interpretation took for its basis four standards existing already at that time: IAS 20 Accounting for State subsidies and

publication of State contribution

IAS 36 Impairment of assets

IAS 37 Earmarked reserves, pending liabilities, pending receivables

IAS 38 Intangible assets

The interpretation tried to solve the problem of the accountancy accounting for emission rights, which problem is derived from several peculiarities of "cap and trade' 5

These are the following:

- The rights define the upper level (cap) of the emission of pollutant, the State undertakes a real role in the distribution. The distribution of rights may be made free of charge or against compensation, the participants pay the State for the rights.

- The scheme influences the frequency of distribution, the periods of annual fulfilment. The licences determine the emissions of the participants at the beginning of the period of fulfilment. The actual emissions are also examined at the end of the period.

- The participants may freely sell and purchase the rights. In consequence thereof the participants have 3 possibilities:

- they keep their pollutant emission at the starting level,

- they keep their pollutant emission below the starting level and sell their superfluous emission rights,

- their pollutant emission is higher than the starting level, in this case they may purchase further rights or they shall pay a fine.

- The participants may sell some or even all of their emissions, in order to repurchase later on the rights corresponding to their presumable emission.

- At the end of the period of fulfilment they have to hand over the prescribed emissions, which are equal to the actual emission. If the operators do not have sufficient right, they have to suffer sanctions. The sanctions may have various forms, among other things fine, reduction of the allocated rights in the next period and/or the restriction of the activity.

- In several schemes the non-used emissions can be carried over to the debit of the emissions of the next period - thus like in our home country as well.

The entitlement distributed by the State or the one which can be purchased is an intangible asset, thus it is covered by IAS 38. The emission right is to be shown at real value, and if the compensation paid is less than the real value of the right, then the

\footnotetext{
${ }^{5}$ Ceiling and trading systems
}

difference is to be accounted for as State subsidy, which subsidy results in deferred revenue, and the deferral shall be released during the period of entitlement (IAS 20).

The subject year's liability on the obligation of the economic unit, according to which it shall hand over the quota corresponding to the actual emissions of the correspondent period, shall be shown as earmarked reserve (IAS 37). This is equal to the market price of the quotas required for the settlement of the obligation. The most accurate evaluation of the obligation is required at the balance sheet date. In connection with the interpretation the participants proposed several times that all expenses still to be expected, e.g. also the costs of a fine or sanction should be taken into consideration upon the evaluation.

These were basically the problems of evaluation which led to the Commission's revocation of the interpretation. We have to mention, however, also the deficiency of IFRIC 3 that it covered only the operators and did not cover the players of the market who participate for the purposes of investment, speculation or even environmental protection in the trading.

\section{Summary}

The further development of the emissions trading scheme of the European Union is an important task. One of the very important elements thereof is that it should be connected with the United Nations' international carbon dioxide emission registers within several weeks, thus the carbon credits issued by the United Nations will be capable of being used also in the scheme of the European Union. We can trust that this will also be an impetus for the legislators in order to eliminate the deficiencies of the regulation.

This study, as its main objective, had to present that the place in the balance sheet of emission rights may only be deduced in general from the domestic and international regulations currently valid. We have to remark, however, that a new production factor came into existence for the undertakings concerned, the national assets are enriched by a quantified natural resource. The financial effects of carbon credits are to be calculated in the future also upon the planning of investment projects. And it is also unambiguous that emission right may represent different values due to utilisation. 


\section{Literature referred to}

1 Cook A, Emission rights: From costless activity to market operations, Accounting, Organizations and Society, posted on February 2008, DOI 10.1016/j.aos.2007.12.001, (to appear in print).

2 Bándi Gy, Manual of Environmental Protection, KJK-KERSZÖV, 2000.

3 MacKenzie D, Making things the same: Gases, emission rights and the politics of carbon market, posted on April 2008, DOI 10.1016/j.aos.2008.02.004, (to appear in print).

4 Horváth Zs, Bándi Gy, Erdey Gy, Pomázi I, Regulation of Environmental Protection in the European Union, KJK-KERSZÖV, 2004.

5 IASB: IFRIC 3 Emission Rights, December 2004.

6 International Financial Reporting Standards.

7 Kerekes S, Szlávik J, Economic Tools of Environmental Management, KJK-KERSZÖV, 2003.

8 Climate Change: Scientific Background and a Possible Political Framework System of Future Commitment Negotiations, February 2006. Ministry of Environmental Protection and Water [KvVM], manuscript.

9 National Distribution Plans of EU Member States - Summarising Work Material, May 2004. Ministry of Economy and Transport.

10 Stern review: The Economics of Climate Change 2006., available at http://www.hm-treasury.gov.uk/media/999/76/CLOSED_HORT_

executive_summary.pdf Downloaded on 21 March 2007.

Further Internet sources:

11 available at http://www.iasb.org/Current+Projects/IASB+ Projects/Emission+Trading+Schemes/Emission+Trading+

Schemes downloaded on 26 July 2008.

12 available at http://www.europa.eu/rapid/pressReleasesAction. do?reference downloaded on 12 January 2006.

13 available at http://www.europa.eu.int/comm/enviroment/climat/ emission/pdf/dir.pdf downloaded on 14 December 2005.

International agreements and legal rules:

14 EU Directive No. 2003/87/EC: Directive 2003/87/EC of the European Parliament and of the Council (13 October 2003) on Establishing a Scheme for Greenhouse Gas Emission Allowance Trading within the Community and amending Council Directive 96/61/EC.

15 EU Directive No. 2004/101/EC: Directive 2004/101/EC of the European Parliament and of the Council (27 October 2004) amending Directive 2003/87/EC on Establishing a Scheme for Greenhouse Gas Emission Allowance Trading within the Community, in respect of the Kyoto Protocol's project mechanisms.

16 Kyoto Protocol, 1997, available at http://www.kvvm.hu/szakmai/ klima/dokumentum/pdf/kp_hun.pdf

17 United Nations Climate Change Frame Agreement, 1997, available at http: //wWw.kvvm.hu/szakmai/klima/dokumentum/pdf/unfcc_hun.pdf

Acts and decrees in Hungary:

18 Act XV of 2005 on Trading in the Emission Units of Greenhouse Gases.

19 Act LIX of 2006 on the Special Tax and Allowance Improving the Balance of the State Budget.

20 Act IV of 2007 on the Promulgation of the Kyoto Protocol Accepted at the Third Meeting of 1997 of the Conference of the Parties Participating in the United Nations' Climate Change Framework Agreement.

21 Act LX of 2007 on the Execution Framework System of the United Nations, Climate Change Frame Agreement and the Kyoto Protocol thereto.

22 Act $C$ of 2000 on Accounting.

23 Act CXX of 2001 on the Capital Market.

24 Government Decree No. 66/2006 (III.27.) on the Promulgation of the National Distribution Plan and National Distribution List relating to the Trading in the Emission Units of Greenhouse Gases and on the Detailed Rules of the Distribution of Emission Units.
25 Government Decree No. 109/2006 (V.5.) on the Detailed Rules of Disposition over the Greenhouse Gases Emission Units, belonging to the Treasury Assets of the Hungarian State.

26 Government Decree No. 213/2006. (X.27.) on Certain Rules of the Execution of Act XV of 2005 on Trading in the Emission Units of Greenhouse Gases.

27 Government Decree No. 13/2008 on the Promulgation of the National Distribution Plan relating to the Period between 2008 and 2012, as well as on the Detailed Rules of the Distribution of Emission Units. 